ISSN 0258-7122

Bangladesh J. Agril. Res. 38(3): 545-552, September 2013 Short Communication

\title{
VARIATION IN SEED QUALITY OF RADISH PRESERVED IN DIFFERENT STORAGE CONTAINERS
}

\author{
M. K. QUAIS ${ }^{1}$, S. JAHAN ${ }^{1}$, M. M. HAQUE ${ }^{2}$ AND M. R. KHAN ${ }^{3}$
}

Keywords: Seed quality, radish seed, and storage container.

Radish (Raphanus sativus), a member of the family Cruciferae, is a popular vegetable in both tropical and temperate regions of the world (Becker, 1962). Radish is an important root vegetable crop widely cultivated for its tender roots as well as succulent foliage and immature pods (used largely in salad and for culinary purposes). Fresh root provides just 16 calories per $100 \mathrm{~g}$, nonetheless, they are a very good source of anti-oxidants, electrolytes, minerals, vitamins and dietary fiber. Fresh roots are rich in vitamin $\mathrm{C}$ and provide about $15 \mathrm{mg}$ of vitamin $\mathrm{C}$ per $100 \mathrm{~g}$. In addition, they contain adequate levels of folates, vitamin B-6, riboflavin, thiamin, and minerals, such as iron, magnesium, copper, and calcium (Urbano, 2012). Production statistics of radish in Bangladesh is 260,000 tons of edible roots. It ranks third in production among the major vegetable crops of Bangladesh (BBS, 2010).

Seed is a living entity and is subjected to various environmental stresses which affect the quality. In storage, the viability and vigour of the seeds not only vary from genera to genera and variety to variety, but it is also regulated by many physico-chemical factors like moisture content, atmospheric relative humidity, temperature, initial seed quality, physical and chemical composition of seed, gaseous exchange, storage structure, packaging materials, etc. (Doijode, 1988). In order to prevent the quantitative and qualitative losses due to several biotic and abiotic factors during storage, several methods are being adopted, such as seed treatment with suitable chemicals or plant products and storing in safe containers, besides sanitation of the storage place (Doijode, 1988). To combat these factors effectively, storing the seeds in vapour proof containers like polythene bag, aluminium foils, tins or any sealed containers is found to be more useful in maintaining the desired quality of seeds for longer period (Gurmithsingh and Harisingh, 1992), unlike those stored in moisture pervious containers like cloth bag and gunny bag (Singh et al., 1988). The information on prolonging the shelf life of radish seeds under storage is very limited and hence the present study has been undertaken to know the suitable packing material for better storage of radish seed and the effect of different storage containers on retention of seed quality over storage period.

\footnotetext{
${ }^{1}$ Senior Scientific Officer, Bangladesh Rice Research Institute (BARI) ，Gazipur, ${ }^{2}$ Professor, Agronomy Division, Bangabandhu Sheikh Mujibur Rahman Agricultural University (BSMRAU), Salna, Gazipur, ${ }^{3}$ Publication Officer, Seed Certification Agency, Gazipur, Bangladesh.
} 
The experiment was conducted during 10 April to 19 June 2011 at Outreach Centre, Bangabandhu Sheikh Mujibur Rahman Agricultural University (BSMRAU), Gazipur. The materials such as seeds of Radish (Raphanus sativus), oven for determination of seed moisture and seedling dry weight, weighing machine, seed counter, plastic box, Substrate (sand), water bottle for germination and wet and dry bulb thermometer for collecting regular relative humidity and temperature, etc. were used for research work. Radish seeds were supplied by the course coordinator, and for the experimental purpose, $1 \mathrm{~kg}$ seeds were stored in metal container (Tin), polythene bag $(0.1 \mathrm{~mm})$ and cloth bag and kept them at room temperature. The experiment was conducted using three storage containers, such as metal container (Tin), polythene bag and c loth bag under different storage periods viz., 10, 25, 40, 55, and 70 days.

The experiment was laid out in completely randomized design (CRD) with four replications. Moisture content was determined by using high constant temperature oven method following International Rules for Seed Testing (Anonymous, 1999). Four to five gram seeds from each container were taken in each replication. After grinding the seeds in grinding mill the weighed ground materials (the seeds) were poured in a small container with cover and kept in an oven maintained at a temperature of $130-133^{\circ} \mathrm{C}$ for a period of 12 hours. The moisture content of seeds (wet basis) was determined by the following formula.

Moisture content $(\%)=\frac{M_{2}-M_{1}}{M_{2}-M 3} \times 100$

Where,

$\mathrm{M}_{1}=$ is the weight in grams of the container and its cover;

$\mathrm{M}_{2}=$ is the weight in grams of the container its cover and its contents seed before drying;

$\mathrm{M}_{3}=$ is the weight in grams of the container its cover and its contents seed after drying .

Germination test was carried out in petridish at room temperature without any pretreatment of seeds. Sand was used as germination media. Adequate moisture level was maintained in the germination media. For this purpose, 400 seeds were randomly taken from the working sample from each storage container. The seeds were placed in 4 petridish, 100-seed in each replication. Data on germination, abnormal seedling, dead seed, and fresh seeds were collected regularly up to final count (ISTA, 1993). Seed vigour was determined by the following formula:

Vigour index $=\frac{\text { No. of seeds germinated (first count) }}{\text { No. of days to first count }}+\Lambda \Lambda \Lambda \Lambda \Lambda$ 


$$
\Lambda \Lambda \Lambda \Lambda \Lambda+\frac{\text { No. of seeds germinated (last count) }}{\text { No. of days to last count }}
$$

The seedling length of 10 plants from each replication was recorded. The seedlings were air dried and then oven dried at $70^{\circ} \mathrm{C}$ for 72 hours. The oven dry weight of seedlings was recorded and from this data, we got the total dry matter per plant. After manual counting of 1000 seeds, it was weighed with the help of weighing machine and data were recorded. The prevailing meteorological information during the study regarding temperature and relative humidity were recorded every day. Prevalence of any kind of infection in seedling was recorded during each germination test and it was converted into percentage.

Moisture content of the seeds of cloth bag, metal container, and polythene bag were found increased from $6.81 \%$ to $10.35 \%, 6.81 \%$ to $8.40 \%$, and $6.81 \%$ to $8.25 \%$, respectively, within 70 days of storage (Table 1). Impervious containers viz., polythene bag and metal container have recorded lower mean moisture content throughout the storage period compared to pervious container (cloth bag). The seeds of cloth bag came to the contact with air and their moisture contents were increased more than the other containers from initial moisture content. As metal container and polythene bag were more or less air tight and the seeds of these containers could not come to the contact with the ambient room air therefore, resulting lower change in their moisture content. Irrespective of storage containers, moisture content of seeds increased gradually with the increase of storage time. Similar result was found by (Miah et al, 1992 and Uddin, 2005).

Table 1. Moisture content of radish seeds and the average temperature and relative humidity of room during storage.

\begin{tabular}{l|c|r|r|r|rc}
\hline \multirow{2}{*}{ Storage container } & \multicolumn{5}{c}{ Moisture content at different days after storage (\%) } \\
\cline { 2 - 7 } & Initial & 10 & 25 & 40 & 55 & 70 \\
\hline Metal container (Tin) & $6.81 \mathrm{i}$ & $6.85 \mathrm{i}$ & $7.14 \mathrm{~h}$ & $7.80 \mathrm{~g}$ & $8.16 \mathrm{e}$ & $8.40 \mathrm{~d}$ \\
Polythene bag $(0.1 \mathrm{~mm})$ & $6.81 \mathrm{i}$ & $6.82 \mathrm{i}$ & $7.10 \mathrm{~h}$ & $7.70 \mathrm{~g}$ & $7.97 \mathrm{f}$ & $8.25 \mathrm{de}$ \\
Cloth bag & $6.81 \mathrm{i}$ & $6.90 \mathrm{i}$ & $7.68 \mathrm{~g}$ & $9.30 \mathrm{c}$ & $9.85 \mathrm{~b}$ & $10.35 \mathrm{a}$ \\
Temperature $\left({ }^{\circ} \mathrm{C}\right)$ & 27.5 & 29 & 31 & 31 & 30 & 32 \\
Relative humidity (\%) & 84 & 89 & 88 & 88 & 85 & 89 \\
\hline
\end{tabular}

The germination percentage of seeds was found decreased with the increase of storage time (Table 2). Germination percentage of the seeds of cloth bag, polythene bag, and metal container were decreased from 96 to $75 \%, 96$ to $83 \%$, and 96 to $82.25 \%$, respectively during 70 days of storage. This decrease was closely related with the high moisture contents of the seeds. Due to high moisture content of seeds of cloth bag, germination percentage decreased rapidly than tin 
pot and polythene bag stored seeds with lower moisture content. Singh and Singh (1990) observed the gain in moisture content of onion seeds stored in cloth bags resulting lower germination percentage compared to sealed storage as it was completely airtight. The germination percentage of seeds stored in polythene bag was found higher than the seeds of other containers in all observations due to lower moisture content of seed. Das (1998) found similar result with P. vulgaris.

Table 2. Germination percentage of radish seeds during the storage period.

\begin{tabular}{l|c|c|c|c|c|c}
\hline \multirow{2}{*}{\multicolumn{1}{c}{ Storage container }} & \multicolumn{5}{c}{ Germination at different days after storage (\%) } \\
\cline { 2 - 7 } & Initial & 10 & 25 & 40 & 55 & 70 \\
\hline Metal container (Tin) & $96 \mathrm{a}$ & $94.00 \mathrm{ab}$ & $91.50 \mathrm{~b}$ & $88.25 \mathrm{c}$ & $85.00 \mathrm{~d}$ & $82.25 \mathrm{ef}$ \\
Polythene bag & $96 \mathrm{a}$ & $95.50 \mathrm{a}$ & $91.75 \mathrm{~b}$ & $87.75 \mathrm{c}$ & $84.25 \mathrm{de}$ & $83.00 \mathrm{de}$ \\
Cloth bag & $96 \mathrm{a}$ & $92.00 \mathrm{~b}$ & $88.25 \mathrm{c}$ & $84.25 \mathrm{de}$ & $80.00 \mathrm{f}$ & $75.00 \mathrm{~g}$ \\
Relative humidity (\%) & 84 & 89 & 88 & 88 & 85 & 89 \\
\hline
\end{tabular}

Irrespective of containers with the increase of moisture percentage, germination percentage of radish seed was decreased (Fig 2). Similar findings have been found by Hanif et al. (2010) and Masum et al. (2010) with jute seed. Higher seed moisture may be the main reason of quick deterioration in the seeds of cloth bag (Nahar et al., 2009). The lower the seed moisture percentage is, the slower is the rate of seed respiration. A slower rate of seed respiration results in a slower rate of deterioration (FAO, 2006).

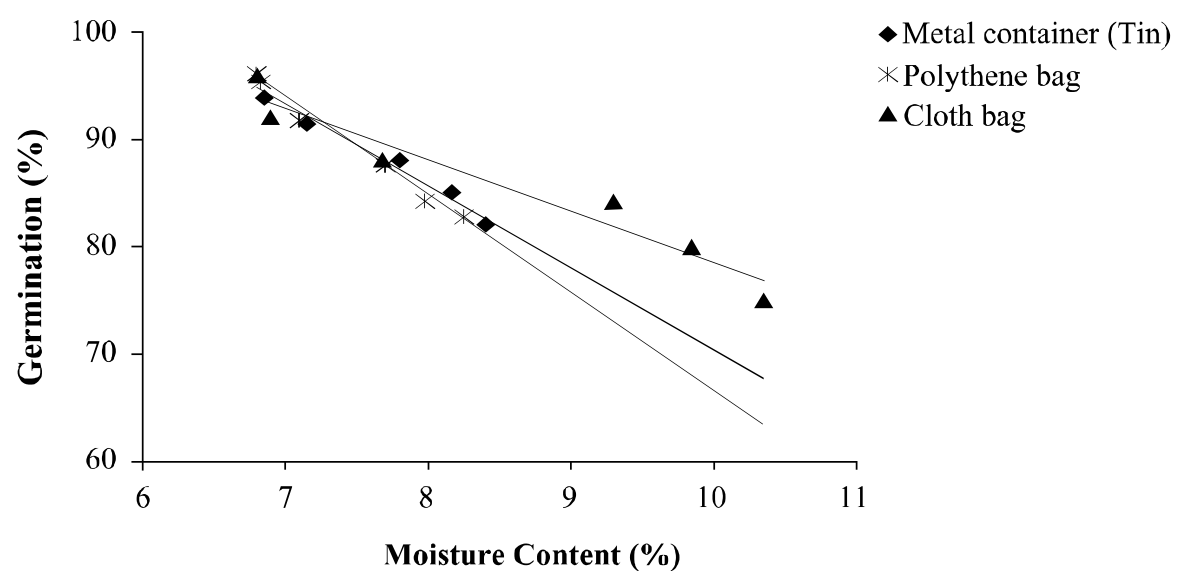

Fig 2. Relationship between germination and MC of radish seeds in metal container (Tin), polythene bag, and cloth bag during storage.

The highest seedling height $(131 \mathrm{~mm})$ was recorded in polybag container at 10 days after storage. The lowest seedling height $(104 \mathrm{~mm})$ was recorded in cloth bag at 70 days after storage (Table 3). Data indicated that seedling height was 
highest in polythene bag in all cases, which was very similar with the values obtained from metallic container. Higher seed moisture in cloth bag may be the main reason of this deterioration. As high seed moisture increases the seed respiration and decreases the seed quality therefore resulting into weak or abnormal seedling (FAO, 2006). Rahman et al. (2006) observed that seedling height of coriander gives highest value in tin than poly bag and jute bag in most cases of observation. Irrespective of storage container, seedling height decreased over time in all cases of observation. Verma et al. (1999) examined the seed lots of Brassica juncea and B. campestris stored under ambient conditions of temperature and humidity. They concluded that with the increasing of seed age germination rate, seedling dry weight, seedling vigour, dehydrogenase activity, protein content, seedling establishment, and seed yield potential decreased.

Table 3. Effect of different containers on seedling height of radish seedling.

\begin{tabular}{l|lll|l|l|l}
\hline \multirow{2}{*}{ Storage container } & \multicolumn{5}{|c}{ Seedling height at different days after storage (mm) } \\
\cline { 2 - 8 } & Initial & 10 & 25 & 40 & 55 & 70 \\
\hline Metal container (Tin) & $132 \mathrm{a}$ & $124 \mathrm{c}$ & $121 \mathrm{~d}$ & $118 \mathrm{e}$ & $115 \mathrm{f}$ & $110 \mathrm{gh}$ \\
Polythene bag & $132 \mathrm{a}$ & $131 \mathrm{a}$ & $128 \mathrm{ab}$ & $125 \mathrm{bc}$ & $121 \mathrm{cde}$ & $117 \mathrm{ef}$ \\
Cloth bag & $132 \mathrm{a}$ & $117 \mathrm{efg}$ & $111 \mathrm{ghi}$ & $108 \mathrm{hij}$ & $106 \mathrm{ij}$ & $104 \mathrm{j}$ \\
\hline
\end{tabular}

The highest value for seedling dry weight $(190 \mathrm{mg})$ was recorded in polythene bag at 10 days after storage. The lowest value for seedling dry weight $(117 \mathrm{mg})$ was recorded in cloth bag at 70 days after storage (Table 4). Table 4 indicated that seedling dry weight was highest in polythene bag in all cases, which was very similar with the values obtained from metal container. Higher seed moisture in cloth bag may be the main reason of this deterioration. As high seed moisture increases the seed respiration and decreases the seed quality therefore, resulting into weak or abnormal seedling (FAO, 2006). Seedling dry weight decreased over time in all cases of observation. Similar findings have been found by Rahman et al. (2006) and Verma et al. (1999).

Table 4. Effect of different containers on seedling dry weight of radish.

\begin{tabular}{l|c|c|r|r|r|c}
\hline \multirow{2}{*}{ Storage container } & \multicolumn{5}{c}{ Seedling dry wt at different days after storage (mg) } \\
\cline { 2 - 8 } & Initial & 10 & 25 & 40 & 55 & 70 \\
\hline Metal container (Tin) & $192 \mathrm{a}$ & $158 \mathrm{~cd}$ & $154 \mathrm{~cd}$ & $148 \mathrm{de}$ & $140 \mathrm{efg}$ & $137 \mathrm{fg}$ \\
Polythene bag & $192 \mathrm{a}$ & $190 \mathrm{a}$ & $182 \mathrm{ab}$ & $174 \mathrm{~b}$ & $161 \mathrm{c}$ & $158 \mathrm{~cd}$ \\
Cloth bag & $192 \mathrm{a}$ & $142 \mathrm{ef}$ & $131 \mathrm{gh}$ & $125 \mathrm{hi}$ & $119 \mathrm{i}$ & $117 \mathrm{i}$ \\
\hline
\end{tabular}

The effect of different containers at different days after storage on seed vigour of radish is shown in Table 5. The highest vigour index (45.04) was found in polythene bag at 10 days after storage. The lowest vigour index was found in cloth bag (22.10) at 70 days after storage (Table 5). Table 5 indicated that vigour 
index was higher in metal container (tin) and polythene bag in all cases than in cloth bag. Vigour index decreased over time in all cases of observation. Vigour index decreased over time due to decreasing trend of germinability of radish seed over time. Germinability of radish seed decreased over time due to different biotic and abiotic factors. The appreciable effect of storage containers on germination percentage was also observed by some other investigators. Harrington (1960) found that high seed moisture is the greatest single cause of losses in viability and vigour.

Table 5. Effect of different containers on seed vigour of radish over time.

\begin{tabular}{l|c|c|c|c|c|c}
\hline \multirow{2}{*}{ Storage container } & \multicolumn{5}{|c}{ Vigour index at different days after storage } \\
\cline { 2 - 7 } & Initial & 10 & 25 & 40 & 55 & 70 \\
\hline Metal container (Tin) & $45.10 \mathrm{a}$ & $44.25 \mathrm{a}$ & $42.92 \mathrm{~b}$ & $40.83 \mathrm{c}$ & $35.88 \mathrm{e}$ & $23.65 \mathrm{~g}$ \\
Polythene bag & $45.10 \mathrm{a}$ & $45.04 \mathrm{a}$ & $43.08 \mathrm{~b}$ & $40.46 \mathrm{c}$ & $36.08 \mathrm{e}$ & $23.98 \mathrm{~g}$ \\
Cloth bag & $45.10 \mathrm{a}$ & $42.92 \mathrm{~b}$ & $41.38 \mathrm{c}$ & $38.88 \mathrm{~d}$ & $33.67 \mathrm{f}$ & $22.10 \mathrm{~h}$ \\
\hline
\end{tabular}

In general, prevalence of fungi was found lower in the seedling stored in polythene bag followed by the seeds of metal container and cloth bag. Among all the fungi was highest in prevalence in the seedlings of cloth bag $15 \%$ followed by metallic container (7\%) and in polythene bag (4\%). Value was lowest in metal container and polythene bag due to lower seed moisture of the seed. Irrespective of storage container, prevalence of fungi increased with the increase of storage time. Rahman and Rahman (2006) observed that sealed metal container (Tin) was the best to prevent the attack of pathogen (fungus) among all the containers under study. According to Justice and Bass (1978) when in storage the moisture content of seed goes above $8-9 \%$ then the risk of insect, fungal \& bacterial attack increases.

Table 6. Prevalence of fungi associated with radish seed during storage.

\begin{tabular}{l|c|c|c|c|c|c}
\hline \multirow{2}{*}{ Storage container } & \multicolumn{5}{|c}{ \% Prevalent of fungi in seedling at different days after storage } \\
\cline { 2 - 7 } & Initial & 10 & 25 & 40 & 55 & 70 \\
\hline Metal container (Tin) & $0 \mathrm{~h}$ & $0 \mathrm{~h}$ & $1 \mathrm{gh}$ & $3 \mathrm{ef}$ & $4 \mathrm{de}$ & $7 \mathrm{c}$ \\
Polythene bag & $0 \mathrm{~h}$ & $0 \mathrm{~h}$ & $0 \mathrm{~h}$ & $2 \mathrm{fg}$ & $2 \mathrm{fg}$ & $4 \mathrm{de}$ \\
Cloth bag & $0 \mathrm{~h}$ & $2 \mathrm{fg}$ & $5 \mathrm{~d}$ & $8 \mathrm{c}$ & $10 \mathrm{~b}$ & $15 \mathrm{a}$ \\
\hline
\end{tabular}

Radish seeds were stored in tin pot, poly bag, and cloth bag in ambient condition for 70 days. Based on the result of the present study, it can be concluded that polythene bag is the best storage container to store radish seed, for maintaining quality. However, metal tin container is also found effective for safe storage of radish seed. Therefore, polythene bag and metal tin container may be recommended for general practice. 


\section{References}

Anonymous. 1999. International Rules for Seed Testing. Seed Sci. Technol. 27:25-30.

BBS. 2010. Yearbook of Agricultural Statistics of Bangladesh Bureau of Statistics. Ministry of Planning, Dhaka.

Becker, G. 1962. Handbush der pflanzenzuchtung 6: 23-78.

Das B. K., I. C. Barua and S. C. Dey 1998. Effect of packing material, storage condition and duration of storage on seed viability, vigour and seedling survivability in rajmah (Phaseolus vulgaris L.). Legume-Research 21(2): 91-95.

Doijode, S. D. 1988. Effect of storage environment on brinjal (Sorghum melongena) seed viability. Pogressive Horticulture 20: 292-293.

FAO. 2006. Quality Declared Seed: Technical Guidelines for Standards and Procedures, FAO Plant Production and Protection Paper 185 Rome, Italy.

Gurmithsingh and Harisingh. 1992. Maintenance of germinability of soybean (Glycine max L.) seeds. Seed Research 20: 49-50.

Hanif, M.A., M. F. Hossain, S.M. Rayhan, S. Parvin and M.O.K. Azad. 2010. Effect of abiotic and biotic factors o the seed quality of Deshi Jute (Corchorus capsularis). Bangladesh Res. Pub. J. 4 (4): 386-390.

Harrington, J. F. 1960. "Drying, storing, and packaging seed to maintain germination, vigor" Seedman's Digest 11(1): 16 56-57, 64, 66, 68.

ISTA. 1993. International rules for seed tasting. Seed Sci. Technol. 13(2):309-343.

Justice, O.L. and L.N. Bass. 1978. Principle \& Practices of Seed Storage. Agricultural Handbook No. 506, Washington, D.C.

Masum, S.M., M.H., Ali, A.K.M.R. Amin, M. Asaduzzaman T.S. Roy. 2010. Effect of abiotic factors on quality of jute seed. Bangladesh Res. Pub. J. 4(1): 47-52.

McCormack, J. H. 2004. Seed Processing and Storage: Principles and Practices, Version1.3, Stanford, California, USA. Pp 9-12.

Miah, M. A. K., A. Ahmed, M. A. Baqui, M. Haq S. M. M. Rahman. 1992. Storage of paddy in rural Bangladesh. Bangladesh Rice J. 3:113-118.

Nahar, K., M.H. Ali, A.K.M. R, Amin and M. Hasanuzzaman. 2009. Moisture Content and Germination of Bean (Phaseolus vulgaris L.) Under Different Storage Conditions. Academic Journal of Plant Sciences 2 (4): 237-241.

Rahman, M.S., I. Hossain and M. A. Mansur. 2006. Effect of storage condition on the quality of wheat seed. Bangladesh J. Agril. Sci. 12(1):49-54.

Rahman, M. M. K. and G. M. M. Rahman. 2006. Seed health studies and crop management in Bangladesh. J. Sust. Agric. 6(2/3): 93-122.

Singh, H. and G. Singh. 1990. Maintenance of germination of onion Seeds. Seed Res. 18:163 - 165 . 
Singh, S. N., S. K. Srivastava, and S. C. Agrawal. 1988. Viability and germination of soybean seeds in relation to pre-treatment with fungicides, period of storage and type of storage conditions. Tropical Agriculture, United Kingdom 65 (2):106-108.

Uddin, M. J. 2005. Effect of storage environment on seed longevity. Hand note, Certificate course of seed technology, Sher-e-Bangla Agricultural University, Dhaka, Bangldesh.

Urbano, L. 2012. Radishes, Retrieved December 4th, 2012, from Montessori Muddle: http://MontessoriMuddle.org/.

Verma, S. S., R. P. S. Tomer U. Verma. 1999. Studies on seed quality parameters in rapeseed (Brassica campestris) and mustard (Brassica juncea) stored under ambient conditions. Indian J. Agril. Sci. 69(12): 840-842. 